\title{
EFL students' reluctance to speak in the classroom - a lesson not learned?
}

ISSN 2657-9774; https://doi.org/10.36534/erlj.2021.02.03

\author{
Thoralf Tews \\ Leibniz University of Hannover \\ thoralf.tews@gmail.com
}

\section{A recapitulation of speaker reluctance before and during the pandemic}

It would be far from true to say the global Covid-19 pandemic is over. Looking at secondary education, however, a number of English teachers must feel that they went full circle: From the 'usual' teaching in a classroom to online-lessons, distance learning, some hybrid models and back to the classroom. Looking back at the time before the outbreak of Coronavirus, teaching English as a foreign language (EFL) included various difficulties, students' reluctance to speak being one of the omnipresent ones.

As a ubiquitous problem, teachers invest great amounts of energy into convincing their students to vocally take part in class - rightly so, given the importance of speaking for the students' development of speaking competence. To build and foster speaking competence, also phrased as communicative ability, verbal student interaction is required in every phase of learning the language. This again relies on positive attitudes towards speaking activities that allow for practice of oral production and reproduction (Szpotowicz 2012, Savaşçı 2013).

Despite all efforts, too little student participation appeared to be a recurring problem already before the pandemic (Savaş̧ı 2013). But when the virus outbreak became a global pandemic and schools switched to online lessons, different studies showed the same pattern: Participation decreased in general and feelings of restraint regarding oral participation grew (Meşe \& Sevilen 2021, Bray et al. 2021, Unger et al. 2020).

Being in a learning situation themselves, teachers had to sort out various difficulties of the online organization of learning, leaving less attention, energy, time and means to work on speaking reluctance - both previously existing or newly developed. It is safe to say that the switch to online education must have been perceived as a setback for the majority of teachers and students in terms of positive learning outcomes. With a more experienced government and society, test schemes, vaccinations and other safety measures, classrooms are now becoming the place of education and physical interaction again. Despite the uncertain outlook on future pandemic developments, the move back into schools has constituted an improvement for many.

Compared to the recent difficulties of online sessions, being physically present in a classroom is a positive development. Unfortunately, this can take away attention from the still prevailing problem of speaker reluctance in EFL classes. Research findings about increased unwillingness to orally participate during the pandemic, as well as the social aftermath of isolation, uncertainty and economical hardships, hint at similar or even increased reluctance of speakers when compared with pre-Covid times (Meşe \& Sevilen 2021, Bray et al. 2021, Unger et al. 2020). Not actively tackling this problem would be a lesson not learned.

But if teachers acknowledge speaker reluctance in EFL classes, then a speaker-friendly environment must be established. This article aims at beginning a list and discussion of methods to create such an environment. Due to the scale of this publication, the list is limited, but open for every person experienced in teaching to extend. First, however, reasons for speaker reluctance need to be identified.

\section{Factors contributing to speaker reluctance}


The EFL classroom deals with a unique context, since it involves a language that most students only speak in this exact setting and are less exposed to than their mother tongue outside of class. Due to this situation, reasons for speaker reluctance can vary between EFL classes and other subjects. Littlewood (2004) defined six factors that impede oral production in EFL settings. The list consists of "tiredness, [...] fear of being wrong, [...] insufficient interest in the class, [...] insufficient knowledge in the subject, [...] shyness" and "insufficient time to formulate ideas" (Savaşçı 2013: 2683). Reluctance is then increased by "fear of public failure, fear of making mistakes, lack of confidence, low English proficiency, inability to keep up with native speakers, incompetence in the rules and norms of English conversation" (ebd., p. 2683). Savaşşı adds cultural specifics to the reasons for reluctance, as some cultures give a more passive role to the educated (2013).

\section{A toolbox of methods to create speaker-friendly environments}

To establish a speaker-friendly environment, different measures can be taken, each addressing one factor of reluctance more than the other. The following methods focus most on shyness.

Since reluctance is gradually established and reluctant speakers still do participate at times, the fear of being incorrect should not be fed by discouraging feedback. One method to correct students in a respectful and encouraging manner is passively correcting. When a student answers a question correct in terms of content, but not in style, the teacher can reply to it, using the right grammar, but confirming the student's utterance content-wise. Such a passive correction, leads by example. Frequent speaker mistakes regarding the same domain, however, hint at an error in the learner's language competence. Such a wrong/missing concept should be divided from mistakes, which are wrong realizations of correct intentions. Errors should be explicitly addressed, but in an encouraging manner. Students rely on such "satisfying teacher feedback", as it has a motivating effect (Meşe \& Sevilen 2021: 19).

Shyness, a hindering factor, constrains oral contributions in the full class collective. While a student might shy away from participating with the attention of all, they would possibly work with a smaller group. The smallest imaginable group would be the shy student, paired with a friend of his/her choice, to ensure an intimate environment for speaking and making mistakes.

Group or single work, preparation time generates "time to formulate ideas", thereby diminishing fears of being wrong (Savaşçı 2013: 2683). Access to dictionaries - especially online ones with a reading function - can add to confidence in the prepared answers.

If the students' fears are not too severe, more forceful methods can be put to test. From the teacher selecting the next speaker to the students selecting themselves by throwing a ball, there are different realizations of the idea of choosing students rather than having them volunteer. While this holds the chance of introducing spontaneity to the classroom and leaving less room for thoughts of reluctance, it also includes a negative experience to those unable to cope with the sudden pressure. These methods call for a reflective teacher, aware of his or her individual students.

\section{Conclusion and outlook}

The toolbox was a personal introduction to a list of methods that can be extended continuously. Each technique comes with possible advantages and disadvantages, and should therefore always be put in a relation with the individual class group, before applying it. As they are tackling different factors of reluctance, a speaker-friendly environment is best created by mixing different methods throughout the lessons.

Going through the online and offline shifts of teaching in the pandemic did demand a lot from teachers. But no matter how positive the return to the classroom feels, it should not put shade on the omnipresent problem of speaker reluctance in foreign language classes. The improvement of reluctance from distance learning to the present is only small and leaves a responsibility to the teachers to reflect 
on their students, their own classroom management and use of methods. At best, Covid-19 turned the focus on an old problem of EFL teaching, while triggering a new confrontation with it.

\section{References}

Bray, A., Banks, J., Devitt, A. \& Chorcora, E. (2021). Connection before content: Using multiple perspectives to examine student engagement during Covid-19 school closures in Ireland, Irish Educational Studies, 40(2): 431-441, Retrieved on November 20, 2021, DOI: 10.1080/03323315.2021.1917444.

Littlewood, W. (2004). Students' perspectives on interactive learning, in: O. Kwo, T. Moore \& J. Jones (Eds). Developing Environments in higher education (pp. 229-245). Hong Kong: Hong Kong University Press.

Meşe, E., Sevilen, Ç. (2021). Factors influencing EFL students' motivation in online learning: A qualitative case study. Journal of Educational Technology \& Online Learning, 4, 11-22. Retrieved on November 20, 2021, from https://files.eric.ed.gov/fulltext/EJ1286748.pdf.

Savaşçı, M. (2013). Why are Some Students Reluctant to Use L2 in EFL Speaking Classes? An Action Research at Tertiary Level. Procedia - Social and Behavioral Sciences, 116, 2682-2686. Retrieved on November 20, 2021, DOI: http://dx.doi.org/10.1016/j.sbspro.2014.01.635.

Szpotowicz, M. (2012). Researching oral production skills of young learners. CEPS Journal, 2(3): 141-166. Retrieved on November 20, 2021, DOI: 10.25656/01:6791.

Unger, V., Krämer, Y., Wacker, A. (2020). Unterricht während der Corona-Pandemie: Ein Vergleich von Schülereinschätzungen aus Baden-Württemberg und Nordrhein-Westfalen im Kontext sozialer Heterogenität. Zeitschrift für Schul- und Professionsentwicklung, 2(6): 84-99. Retrieved on November 20, 2021, DOI: https://doi.org/10.4119/pflb-3907. 